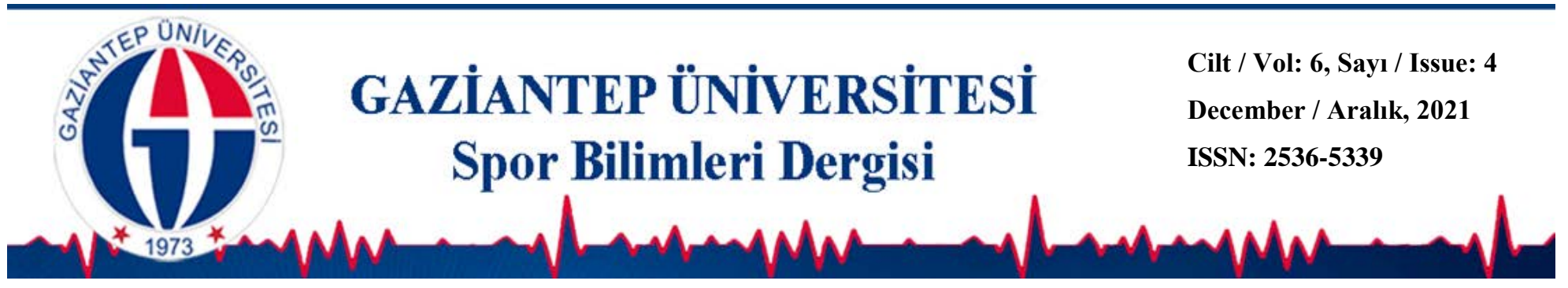

Spor Turizmi ve Gönüllülük

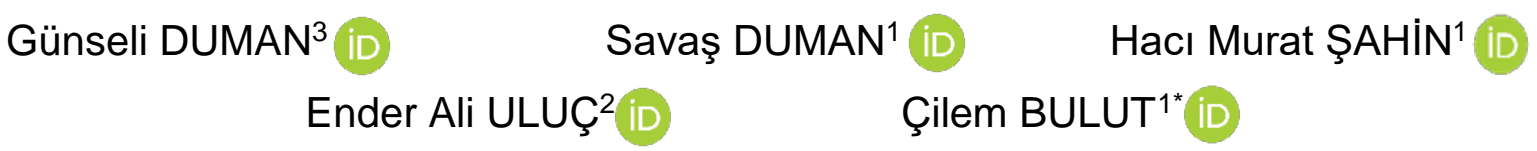

\author{
${ }^{1}$ Adnan Menderes Üniversitesi Spor Bilimleri Fakültesi, AYDIN \\ ${ }^{2}$ Çanakkale Onsekiz Mart Üniversitesi, Ayvacık Meslek Yüksekokulu, ÇANAKKALE \\ ${ }^{3}$ Adnan Menderes Üniversitesi, Yabancı Diller Yüksekokulu, AYDIN
}

do:DOI: 10.31680/gaunjss.1019029

Orijinal Makale / Original Article

Geliş Tarihi / Received: 11.08.2021 Kabul Tarihi / Accepted: 29.11.2021 Yayın Tarihi / Published: 24.12.2021

Öz

Turizmin içerisinde yer alan spor turizmi; spor aktivitelerini yapmak ya da izlemek amacıyla yapılan seyahatleri içermektedir. Uluslararası ya da ulusal düzeyde düzenlenen spor organizasyonları, turlar ya da şampiyonalara katıım sağlayan bireylerin serbest zamanlarını değerlendirmek için yaptıkları seyahatlerin tümü turizmin içerisinde yer almaktadır. İçerisinde yaşadığımız dönemde başta futbol olmak üzere birçok spor branşında gerek ulusal gerekse uluslararası düzeyde spor organizasyonları düzenlenmektedir. Ayrıca sporun ve spor yapılabilecek olan alanların büyümesi spor turizmi baş̧ığı altında golf turizmi, futbol turizmi, hava sporları turizmi, su sporları turizmi gibi birçok alt turizm türünün ortaya çıkmasına olanak tanımıştır. Spor Turizmi kapsamında birçok spor organizasyonu düzenlenmekte ve bu organizasyonlara çeşitli ülkeler ve bölgelerden katılımcılar gelmektedir. Ayrıca ulusal ya da uluslararası düzeyde düzenlenen spor organizasyonlarına birçok gönüllü katılım sağlamaktadır. Gönüllü olarak spor organizasyonlarına katıtım sağlayan bireyler bu organizasyonlarda birçok görev ve sorumluluğu yerine getirmektedirler. Ayrıca bu gönüllüler spor organizasyonları aracılığı ile spor turizmine de katkı sağlamaktadırlar. Spor turizmi kapsamında gönüllük kavramının döküman analizi yöntemiyle incelendiği bu araşıırmada sonuç olarak; Spor organizasyonlarına gönüllü olarak katıım sağlayan bireyler; ekonomik açıdan verimliliğin sağlanması ile birlikte, spor etkinliklerinde maliyetlerin en az düzeye indirilmesi ve aynı zamanda finansal açıdan başarının sağlanmasına imkân tanımaktadırlar.

Anahtar Kelimeler: Spor, Turizm, Gönüllü, Organizasyon

\title{
Abstract
}

\section{Sports Tourism and Volunteering}

Sports tourism, which is included in tourism; It includes travels made for the purpose of doing or watching sports activities. All of the travels of individuals who participate in international or national sports organizations, tours or championships to evaluate their free time are included in tourism. In the period we live in, both national and international sports organizations are organized in many sports branches, especially football. In addition, the growth of sports and areas where sports can be done has allowed the emergence of many sub-tourism types such as golf tourism, football tourism, air sports tourism, water sports tourism under the title of sports tourism. Many sports organizations are organized within the scope of Sports Tourism and participants from various countries and regions come to these organizations. In addition, many volunteers participate in national or international sports organizations. Individuals who participate in sports organizations voluntarily fulfill many duties and responsibilities in these organizations. In addition, these volunteers contribute to sports tourism through sports organizations.

As a result of this research, in which the concept of volunteering within the scope of sports tourism is examined by document analysis method; Individuals who voluntarily participate in sports organizations; Along with providing efficiency in terms of economy, they provide the opportunity to minimize the costs in sports events and to ensure financial success at the same time.

Keywords: Sports, Tourism, Volunteer, Organization.

\footnotetext{
*Sorumlu Yazar: Çilem BULUT

e-mail: bulutcilem0@gmail.com

**Bu araştırma V. Uluslararası Akademik Spor Araştırmaları Kongresinde Sözel Bildiri Olarak Sunulmuştur
} 


\section{Giriş}

Turizmin içerisinde yer alan spor turizmi; Ross (2001)'a göre, spor aktivitelerini yapmak ya da izlemek amacıyla yapılan seyahatleri içermektedir. Bektaş (2010)'a göre, uluslararası ya da ulusal düzeyde düzenlenen spor organizasyonları, turlar ya da şampiyonalara katılım sağlayan bireylerin serbest zamanlarını değerlendirmek için yaptıkları seyahatlerin tümü turizmin içerisinde yer almaktadır. İçerisinde yaşadığımız dönemde başta futbol olmak üzere birçok spor branşında gerek ulusal gerekse uluslararası düzeyde spor organizasyonları düzenlenmektedir. Ayrıca sporun ve spor yapılabilecek olan alanların büyümesi spor turizmi başlığı altında golf turizmi, futbol turizmi, hava sporları turizmi, su sporları turizmi gibi birçok alt turizm türünün ortaya çıkmasına olanak tanımıştır. Spor turizmi kapsamında birçok spor organizasyonu düzenlenmekte ve bu organizasyonlara çeşitli ülkeler ve bölgelerden katılımcılar gelmektedir. Ayrıca ulusal ya da uluslararası düzeyde düzenlenen spor organizasyonlarına birçok gönüllü katılım sağlamaktadır. Gönüllülük kavramı latince "voluntas" kelimesinde türemiştir. Ferrand ve Chanavat (2006)'a göre, zorunlu ihtiyaçların dışında bireylerin başka insanlara fayda sağlamak için herhangi bir maddi karşılık beklemeden eylemlerde bulunan kişiler gönüllü olarak ifade edilmektedir. Ringuet (2012)'e göre, gönüllüler herhangi bir maddi kazanç gözetmeksizin diğer insanların yararı için zaman ve çaba harcamaktadırlar.

Günümüzde düzenlenen spor organizasyonları, küresel ölçekte çok önemli bir yere sahiptir (Bjelac ve Radovanovic, 2003). Basım ve Argan (2009)'a göre, hazırlık turnuvaları, yerel ve bölgesel müsabakalar ulusal spor organizasyonları içerisinde yer alırken, olimpiyatlar, dünya şampiyonaları uluslararası spor organizasyonları içerisinde yer almaktadır. Hazar (2007)'a göre, uluslararası düzeyde gerçekleştirilen spor organizasyonlarının sayısı gün geçtikte artış göstermektedir. Meydana gelen bu artışa bağlı olarak birçok ülke spor organizasyonlarına ev sahipliği yapmak için yoğun bir çaba harcamaktadırlar. Gerek uluslararası gerekse ulusal olarak düzenlenen spor organizasyonlarına birçok gönüllü katılım sağlamaktadır. Gönüllü olarak spor organizasyonlarına katılım sağlayan bireyler bu organizasyonlarda birçok görev ve sorumluluğu yerine getirmektedirler. Ayrıca bu gönüllüler spor organizasyonları aracılığı ile spor turizmine de katkı sağlamaktadırlar. Buradan hareketle bu araştırmanın amacı; spor turizmi kapsamında gönüllük kavramının incelenmesidir. 


\section{Turizm}

Latince "tornus" sözcüğünden türeyen turizm kavramı kelime anlamı olarak dönmek hareketini ifade etmektedir (Demirel, 2021). İngilizcede yer alan "touring" ve "tour" sözcükleri ise latince "tornus" sözcüğünden türemiştir. T.C. Kültür ve Turizm Bakanlığı (2019)'na göre, İngilizce 'de dairesel olarak bir hareketi ifade eden turizm kavramı, ülke, şehir ve bölgelere ziyaret amacıyla yapılan yer değiştirme hareketini ifade etmektedir. Demirel (2021)'e göre, 19. Yüzyılda İngilizlerin Avrupa'ya yapmış oldukları seyahatler için turizm sözcüğü kullanılmıştır. Pehlivan (2010)'a göre, 20. Yüzyılda meydana gelen bir takım siyasi olaylardan 1930 yılında Alman filozoflar Arthur Bormann ve Hubert Golden turizmin aktif öğesi olan ulaştırma faktörünü, bireylerin bulundukları bölgeden geçici bir süreliğine yer değiştirmelerini esas almışlar ve yapılan turizm tanımlamalarında ulaşıma da yer vermişlerdir. Eski dönemlerde varlıklı ve serbest zamanları fazla olan bireylerin yaptıkları geziler ve ulaşım olanaklarının gelişmesiyle turizm gün geçtikçe gelişmiş ve yaygınlaşmıştır (Pehlivan, 2010).

\section{Spor Turizmi}

Ross (2001), spor aktivitelerinin yapılması veya izlenmesi için yapılan seyahat deneyimlerini spor turizmi olarak ifade etmektedir Bektaş (2010)'a göre, uluslararası veya ulusal düzeyde sportif bir aktiviteyi içeren organizasyonlara katılım sağlayan bireylerin amacı; serbest zaman değerlendirme ya da yarışma isteği olarak görülmektedir. Ulusal ya da uluslararası düzeyde gerçekleştirilen bu turnuvalar temelinde; sportif etkinliklere katılım sağlamak için yapılan seyahatleri içeren turizm hareketi olarak görülmektedir. Spor turizminin tarihi incelendiğinde; Milattan önce 766 yılında düzenlen Eski Yunan olimpiyat oyunları Albayrak (2013)'e göre, ilk spor turizmi organizasyonlarından birisi olarak gösterilebilir. Tarınç (2019)'a göre, yıllar geçtikçe insanların spora olan ilgi ve merakları artmış ve böylelikle spor organizasyonlarının sayısında artış yaşanmıştır. Günümüzde futbol branşı başta olmak üzere farklı spor branşlarında birçok spor organizasyonu düzenlenmektedir. Sporun gün geçtikçe yaygınlaşması, farklı spor branşlarının ortaya çıkması, spor yapılabilecek alanların gelişme göstermesi, spor turizmi başlığı altında golf turizmi, hava sporları turizmi ve su sporları turizmi gibi spor turizminin birçok alt türünün ortaya çıkmasına olanak tanımıştır. 


\section{Yapılış Amacına Göre Spor Turizmi Çeşitleri}

Spor turizmi çeşitleri; olay tabanlı spor turizmi, aktif spor turizmi ve nostalji spor turizmi olmak üzere üç grupta incelenmektedir.

Olay Tabanlı Spor Turizmi: Herhangi bir spor branşında düzenlenen Olimpiyatlar, Dünya Kupaları gibi organizasyonların içerisinde yer aldığı spor turizmi çeşidi olay tabanlı spor turizmi şeklinde tanımlanabilir (Osmanoğlu, 2017). Aktif Spor Turizmi: İlgili spor branşlarında müsabık sporcu olarak katıım sağlayan katılımcıların aynı zamanda spor turisti olarak seyahatlere katılım sağlaması aktif spor turizmi kapsamında değerlendirilmektedir (Parks, Quarterman ve Thibault 2013). Nostalji Spor Turizmi: Osmanoğlu (2017)'na göre, nostalji spor turizminde gidilen yerlerin tamamı tarihi ya da sembolik bir özellik taşımaktadır. Parks ve diğerleri (2013)'ne göre, sportif açıdan tarihsel öneme sahip olan yerleri görmek için katılımcıların turist olarak seyahatlere katılım sağlaması nostalji spor turizmi kapsamında değerlendirilmektedir.

\section{Gönüllülük Kavramı}

Gönüllülük kavramı latince "voluntas" kelimesinde türemiştir. Ferrand ve Chanavat (2006)'a göre, zorunlu ihtiyaçların dışında başka insanlara fayda sağlamak için herhangi bir maddi karşılık beklemeden eylemlerde bulunan kişiler gönüllü olarak ifade edilmektedir. Ringuet (2012)'e göre, gönüllüler herhangi bir maddi kazanç gözetmeksizin diğer insanların yararı için zaman ve çaba harcamaktadırlar. Ardahan (2015)'a göre, bireylerin serbest zamanlarında, herhangi bir maddi çıkar gözetmeksizin başka bireylere fayda sağlaması durumu gönüllülük olarak ifade edilmektedir.

Gönüllülük; herhangi bir maddi çıkar gözetmeksizin ya da başka bir bireyin çıkar beklentisi içerisinde olmadan; diğer bireylerin yaşam standartlarını arttırmak ya da topluma fayda sağlamak için sivil toplum örgütleri içerisinde yer alan etkinlere destek olması durumudur (Bektaş, 2021). Güder (2006)'a göre; bir gönüllüde bulunması gereken ilk özellik samimi olmasıdır.

Bir bireyin gönüllü olmasındaki temel nedenlerden bazıları şu şekilde sıralanabilir (Göker, 2009; Güçlü, Türkmen, Ilgaz ve Akman, 2013; Güzel ve Ünlü, 2015).

1. Bir değişim sürecinde yer almak.

2. Serbest zamanları faydalı bir iş doğrultusunda değerlendirmek.

3. Eğlenceli vakit geçirmek.

4. Hayat telaşı içinden kaçmak.

5. Yardım duygularını tatmin etmek.

6. Yeni deneyimler kazanmak 
7. Inandıklarının arkasında durmak, destek vermek.

8. Çevre ve sosyal alanlarını geliştirme çalışmalarına katkı sağlamak.

9. Toplumsal problemlere çözüm bulmak, fark yaratmak, yararlı olmak.

10. Kendi davranışları ve gelecekleri için sorumluluk almak.

\section{Spor Organizasyonlarında Gönüllülük}

Günümüzde spor organizasyonları; küresel ölçekte ülkeler için oldukça büyük bir öneme sahiptir (Bjelac ve Radovanovic, 2003). Sunay (2010)'a göre, uluslararası spor organizasyonları Olimpiyatlar, Dünya, Avrupa, Balkan Şampiyonaları şeklinde sıralanmaktadır. Basım ve Argan (2009)'a göre, hazırlık turnuvaları, bölgesel müsabakalar ulusal spor organizasyonları içerisinde yer almaktadır. Slack ve Parent (2006)'e göre, spor organizasyonları, spor endüstrisi içerisinde sosyal bir varlık olarak görülmektedir. Hazar (2007)' e göre, uluslararası düzeyde gerçekleştirilen spor organizasyonlarının sayısı gün geçtikte artış göstermektedir. Meydana gelen bu artışa bağlı olarak birçok ülke spor organizasyonlarına ev sahipliği yapmak için yoğun bir çaba harcamaktadırlar. Gerek uluslararası gerekse ulusal olarak düzenlenen spor organizasyonlarına birçok gönüllü katılım sağlamaktadır. Gönüllü olarak spor organizasyonlarına katııım sağlayan bireyler bu organizasyonlardan birçok görev ve sorumluluğu yerine getirmektedirler. Ayrıca bu gönülüler spor organizasyonları aracılığı ile spor turizmine de katkı sağlamaktadırlar.

Spor organizasyonlarında görev alan gönülülerin alabileceği görevler Şekil 1'de gösterilmiştir.
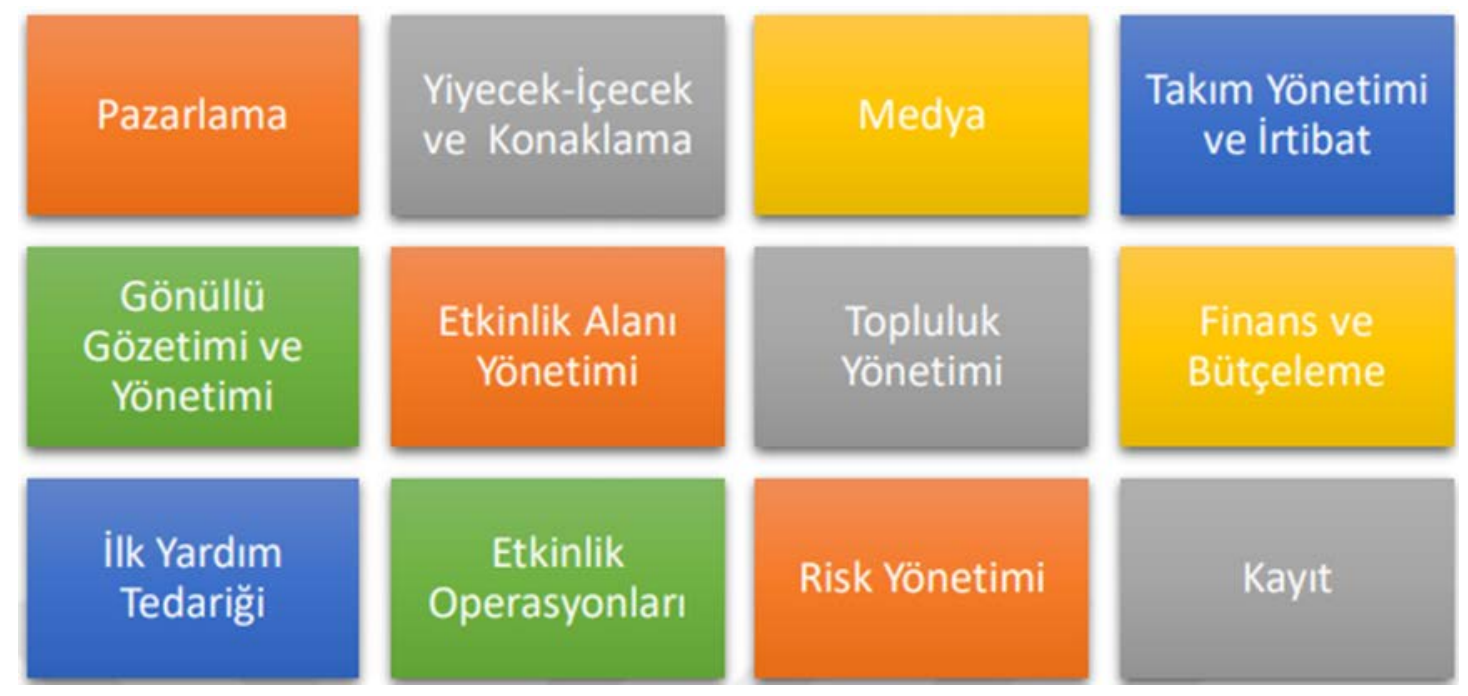

ilk Yardım

Etkinlik

Operasyonları

Risk Yönetimi

Kayit

Şekil 1. Uluslararası spor organizasyonlarında gönüllülerin rolleri. Kaynak: Ringuet (2012). 
Şekil 1'de görüldüğü üzere, uluslararası spor organizasyonlarına gönüllü olarak katıım sağlayan bireyler; pazarlama, yiyecek-içecek ve konaklama, medya, takım yönetimi ve irtibat, gönüllü gözetimi ve yönetimi, etkinlik alanı yönetimi, topluluk yönetimi, finans ve bütçeleme, ilk yardım tedariği, etkinlik operasyonları, risk yönetimi ve kayıt gibi bölümlerde gönüllü olarak yer alabilmektedirler. Ahn (2018)'a göre, başlıca olimpiyat oyunu organizasyonlarından yaz ve kış oyunları gönüllü katııımcı sayıları tablo 1 'de gösterilmektedir.

Tablo 1. Olimpiyat Oyunu Organizasyonlarından Olan Yaz ve Kış Oyunları Gönüllü Katılımcı Sayıları

\begin{tabular}{llll}
\hline Yaz Oyunları & $\begin{array}{l}\text { Gönüllü } \\
\text { Sayısı }\end{array}$ & Kış Oyunları & $\begin{array}{l}\text { Gönüllü } \\
\text { Sayısı }\end{array}$ \\
\hline Los Angeles, ABD, 1984 & 28,742 & Sarajevo, Yugoslavya, 1984 & 10,450 \\
Seul, Güney Kore, 1988 & 27,221 & Calgary, Kanada, 1988 & 9498 \\
Barselona, İspanya, 1992 & 34,548 & Albertville, Fransa, 1992 & 60,422 \\
Atlanta, ABD, 1996 & 60,422 & Lillehammer, Norveç, 1994 & 9054 \\
Sydney, Avustralya, 2000 & 46,967 & Nagano, Japonya, 1998 & 32,000 \\
Atina, Yunanistan, 2004 & 45,000 & Salt Lake City, ABD, 2002 & 22,000 \\
Beijing, Çin, 2008 & 70,000 & Turin, İtalya, 2006 & 18,000 \\
Londra, İngiltere, 2012 & 70,000 & Vancouver, Kanada, 2010 & 18,500 \\
Rio, Brezilya, 2016 & 50,000 & Sochi, Rusya, 2014 & 25,000 \\
Tokyo, Japonya, 2020 & 80,000 & PyeongChang, Güney Kore, 2018 & 23,000
\end{tabular}

Kaynak: Ahn (2018).

Er (2020)'e göre, uluslararası düzeyde gerçekleştirilen spor organizasyonları içerisinde yer alan olimpiyatlar, gönüllüler açısından en büyük talebi sunmaktadır. Ayrıca spor organizasyonlarında etkinliklerin gerçekleştirilmesi için gönüllülere güvenmektedirler. Mallen ve Adams (2008)'e göre, uluslararası spor organizasyonlarında gönüllüler önemli bir rol oynamaktadırlar.

\section{Spor Organizasyonları ve Gönüllüğün Önemi}

İnsan kaynağı, diğer tüm kaynaklarla birlikte, spor organizasyonlarının başarılı şekilde gerçekleştirilmesi için hayati öneme sahiptir (Bowdin, Allen, O’Toole, Harris, McDonnel, 2001; Kumnig ve diğerleri, 2014). Yetenekli insan kaynağının organizasyonlara çekilmesi ve onlardan yararlanılması spor organizasyonlarının başarılı bir şekilde düzenlenmesine katkı sağlayacağı düşünülmektedir. Bulut (2021)' e göre, spor organizasyonlarında yer alan gönüllüler; belirli bir amaca destek olmak ve yardım etmek için becerilerini kullanmaktadırlar. Günümüzde spor, gönüllülük yapılan en önemli alandır ve çoğu ülkede spor gönüllüleri organizasyonlara katkı sunan en 
Duman G, Duman S, Şahin HM, Uluç EA, Bulut Ç. (2021).Spor Turizmi ve Gönüllülük. Gaziantep Üniversitesi Spor Bilimleri Dergisi, 6(4), 384-395.

büyük gönüllü kategorisini oluşturmaktadır. Sporda profesyonel kadroların istihdam edilmesindeki artış oranına rağmen, gönüllülerin sporun gelişimine ve sürdürülebilirliğine yaptığı büyük katkılar, onların spor sisteminin geleceği açısından büyük bir öneme sahip olduğunu göstermektedir (Cuskelly Hoye ve Auld, 2006).

Olimpiyatlar, Paralimpik Oyunlar, Dünya Kupaları gibi büyük ve çoklu spor organizasyonları, temel hizmetlerin gerçekleştirilmesinde büyük oranda gönüllülere güvenilmektedir (Hoye, Smith, Westerbeek, Stewart, Nicholson, 2006; Neufeind, Güntert ve Wehner 2013). Gönüllülerin çabaları olmadan global düzeydeki bu büyük organizasyonların sürdürülmesi mümkün görünmemektedir (Kemp 2002; Green, Chalip 2004; Giannoulakis, Wang ve Gray, 2008). Benzer şekilde, ulusal ve yerel organizasyonların yöneticileri de organizasyonlarda gönüllülerin bilgi ve becerilerinden faydalanmaktadırlar (Cuskelly, Hoye ve Auld, 2006). Gratton, Nichols, Shibli ve Taylor (1997) spor gönüllüsünü, sporla ilgili faaliyetlerde, kulüpler veya federasyonlar gibi bir yapı içerisinde, başkalarına yardım eden, karşılığında bir ücret almayan veya sadece masrafları için harçlık alan kişiler şeklinde tanımlamaktadır.

\section{Spor Turizmi ve Gönüllülük}

Fişne (2017)'e göre, gönüllüler uluslararası spor organizasyonlarında oldukça önemli bir rol oynamaktadırlar. Bu çoklu spor organizasyonları birçok gönüllüyü kapsamaktadır. Olimpiyat oyunları açık arayla gönüllüler açısından en büyük talebi sunmaktadır. Bununla birlikte diğer birçok uluslararası çoklu ya da tekli spor organizasyonun da etkinliğin gerçekleştirilebilmesi için gönüllülere güvenmektedir. Bu örneklerin her biri, gönüllülerin uluslararası spor organizasyonlarında oynadığı önemli rolü göstermektedir (Mallen ve Adams, 2008). Organizasyonlardaki gönüllülüğünün etkisinin, organizasyonun ötesine uzandığı ve hem katılım gösteren gönüllü bireyleri hem de organizasyonun düzenlendiği ev sahibi toplumu olumlu yönde etkilediği görülmektedir. Bulut (2021)'e göre, spor turizminde ve spor sektörü içerisinde en önemli insan kaynağı gönüllüler olarak görülmektedir. Gönüllüler spor endüstrisinin ayrılmaz bir parçasıdır. Mirsafian ve Mohamadinejad (2011)'e göre, bu durumun temel sebebi şu şekilde sıralanabilir;

1. Ekonomik açıdan verimliliğin sağlanması

2. Yeni ve taze fikirlerin ortaya çıkması

3. Spor etkinliklerinde maliyetleri en az düzeye indirmeye olanak tanıması

4. Spor etkinliklerinde finansal başarıyı sağlaması 
Sidney 2000 Yaz Olimpiyat Oyunları içerisinde görev alan gönüllülerin toplam çalışma saati 545.0000, bu çalışma saati dikkate alınarak toplam 109. 756. 925. \$ ekonomik kazanç sağlamıştır (Güngör, 2014). Devecioğlu, Karakaya ve Kara (2020)'e göre, 2020 Tokyo olimpiyatlarında spor gönüllüsü alanları ve tahmini gönüllü sayıları tablo 2'de gösterilmektedir.

Tablo 2. Tokyo olimpiyatlarında spor gönüllüsü alanları ve tahmini gönüllü sayıları

\begin{tabular}{|c|c|}
\hline Alanlar ve Roller & Gönüllü Sayısı \\
\hline Herhangi bir alan veya rol & - \\
\hline Rehberlik & $16000-25000$ \\
\hline Etkinlikler & $15000-17000$ \\
\hline Güvenlik desteği & $10000-14000$ \\
\hline Kişilerarası Destek & $8000-12000$ \\
\hline Operasyonel Destek & $8000-10000$ \\
\hline Sağlık hizmeti & $4000-6000$ \\
\hline Teknoloji & $2000-4000$ \\
\hline Medya & $2000-4000$ \\
\hline Törenler & $1000-2000$ \\
\hline Toplam & $66000-90000$ \\
\hline
\end{tabular}

Tokyo 2020 olimpiyatları için Tablo 2 incelendiğinde; toplam gönüllü sayısının 66.000-90.000 kişi olduğu görülmektedir. Toplam gönüllü sayısı spor turizminin sosyokültürel etkileri kapsamında değerlendirildiğinde; çeşitli bölge ve ülkelerden katılım saplayan gönüllülerin; düzenlenen organizasyonların renkli ve heyecanlı bir ortamın yaratılmasına olanak tanıyacağı düşünülmektedir. Ekonomik açıdan değerlendirildiğinde ise; ülkelerde ekonomik açıdan verimliliğin sağlanmasına, düzenlenen organizasyonların maliyetlerinin en az düzeye inmesine olanak tanıyacağı düşünülmektedir. Aynı zamanda organizasyonlara gönüllü katılımın sağlanması, sürdürülebilir toplum turizmi, topluluk içinde daha fazla sosyal sermaye yaratma fırsatı ve kamu sektörü performansının iyileştirilmesi gibi faydalar sağlamaktadır.

\section{Tartışma ve Sonuç}

Spor turizmi kapsamında gönüllülüğün incelenmesi amacıyla yapılan bu araştırmada spor turizmi ve gönüllük ile ilgili literatür taranarak ilgili araştırmalar incelenmiştir. Spor Turizmi kapsamı içerisinde yer alan uluslararası spor organizasyonları ve gönüllülüğün incelendiği birçok araştırma yer almaktadır. Ancak Spor turizmi kapsamında gönüllülüğün incelenmesi ile ilgili literatürde yapılan araştırmaların az sayıda olduğu görülmüştür. Bektaş (2021)'e göre, dünya çapında 
düzenlenen spor organizasyonları, küresel ekonomiyi hareketlendirmesiyle birlikte maddi olarak büyük bir yükü de beraberinde getirmektedir. Düzenlenen bu etkinliklere gönüllü bireylerin katılım sağlaması ekonomik açıdan düşünüldüğünde milyon dolarlar ile ifade edilebilir. Berber ve Terekli (2019)'ye göre, gönüllüler hiçbir dayatmaya maruz kalmadan kendi hür iradeleri ve istekleri ile etkinliklere katılım göstermekte, zaman ve enerjilerini bu tür etkinliklerin başarılı bir şekilde ortaya çıkmasında harcamaktadırlar.

Spor turizmi kapsamında gönüllülüğün değerlendirilmesi amacıyla yapılan bu araştırmada sonuç olarak; Spor turizmi kapsamı içerisinde düzenlenen organizasyonlara gönüllü olarak katılan bireyler organizasyonun düzenlediği ülkeye de olumlu yönde katkı sağlamaktadırlar. Bunun yanında etkinliklerde var olan gönüllü katılımı, toplumların turizmine, katma değer yaratmaya da olanak tanımaktadır

\section{Kaynaklar}

Ahn, Y. J. (2018). Recruitment of volunteers connected with sports mega-events: A case study of the PyeongChang 2018 Olympic and Paralympic Winter Games. Journal of destination marketing \& management, 8, 194-203.

Albayrak, A. (2013). Alternatif Turizm. Ankara: Detay Yayıncılık.

Ardahan, F. (2015). Ciddi Boş Zaman Faaliyeti Olarak Gönüllülük: Akut Örneği. III. Rekreasyon Araştırmaları Kongresi Bildiri Kitabı, 40-53.

Basım, N. ve Argan, M. (2009). Spor Yönetimi. Detay Yayıncılık.

Bektaş, F. (2010). Kaçkar Havzası Trekking Parkurlarının Spor Turizmi Bakımından Değerlendirilmesi, Yayımlanmamış Doktora Tezi, Gazi Üniversitesi, Eğitim Bilimleri Enstitüsü, Ankara.

Bektaş, S. (2021). Spor Etkinliklerinde Gönüllülük Motivasyonu. Yayımlanmamış Yüksek Lisans Tezi, Pamukkale Üniversitesi, Sosyal Bilimler Enstitüsü, Spor Yöneticiliği Anabilim Dalı, Spor Yönetimi Programı, Denizli

Berber S. ve Terekli M. S. (2019). "Spor Etkinliklerinde Gönüllü Yönetimi ve Motivasyonu". GSI Journals Serie A: Advancements in Tourism Recreation and Sports Sciences, 2(1), 95-121.

Bjelac, Z. ve Radovanovic, M. (2003). Sports events as a form of tourist product, relating to the volume and character of demand. Journal of Sport tourism, 8(4), 260-269.

Bowdin, G, A. J., Allen, J., O'Toole, W., Harris, R. ve McDonnell L. (2001). Events Management. Burlington: Elsevier 
Bulut, B. A. (2021). Uluslararası Spor Organizasyonlarında Görev Alan Gönüllülerin Kişilik Özelliklerinin Sporda Gönüllülük Motivasyonları Üzerine Etkisinin İncelenmesi (İstanbul Örneği). Yayımlanmamış Doktora Tezi, İstanbul Gelişim Üniversitesi, Lisans Üstü Eğitim Enstitüsü, Antrenörlük Anabilim Dalı, Spor Yönetimi Bilim Dalı, İstanbul.

Cuskelly, g. Hoye R. ve Auld C. (2006). Working with Volunteers in Sport. New York: Routledge.

Demirel, O. E. (2021). Turizm Faaliyetlerinin Kent İçi Ulaşım Ağına Etkileri ve Çözüm Önerileri (Reşadiye Örneği). Yayımlanmamış Yüksek Lisans Tezi, Tokat Gaziosmanpaşa Üniversitesi, Fen Bilimleri Enstitüsü, İnşaat Mühendisliği Anabilim Dalı, Tokat.

Devecioğlu, S., Karakaya, Y. E. ve Kaya, O. (2020). Spor Organizasyonlarında Gönüllülük Faaliyetlerinin Yönetim Stratejileri ve Uygulamaları. Spor ve Performans Araştırmaları Dergisi, 11(1), 80-93.

Er, B. (2020). Uluslararası Spor Organizasyonlarında Gönüllü Motivasyonu ile Serbest Zaman Doyum Düzeyi Arasındaki İlişkinin İncelenmesi. Yayımlanmamış Yüksek Lisans Tezi, Manisa Celal Bayar Üniversitesi, Sosyal Bilimler Enstitüsü, Rekreasyon Anabilim Dalı, Rekreasyon Programı, Manisa.

Er, B. ve Güzel Gürbüz, P. (2021). Uluslararası Spor Organizasyonlarında Gönüllü Motivasyonu ile Serbest Zaman Doyum Düzeyi Arasındaki Ilişkinin İncelenmesi. Spor Bilimleri Araştırmaları Dergisi, 6(1), 152-172

Ferrand, A. ve Chanavat, N. (2006). Guidebook for the management of sport event volunteers. How to manage human Ressources, Sentedalps Consortium.

Fişne, M. (2017). Kişilik Özelliklerinin Sporda Gönüllülük Motivasyonu Üzerine Etkisi: Uluslararası Spor Organizasyonlarında Görev Alan Gönüllülere Yönelik Bir Araştırma. Yayımlanmamış Doktora Tezi, Cumhuriyet Üniversitesi, Sosyal Bilimler Enstitüsü, İşletme Anabilim Dalı, Sivas.

Giannoulakis, C., Wang, C.H. ve Gray, D. (2008). "Measuring Volunteer Motivation in Mega-Sporting Events". Event Management. 11(4): 191-200.

Göker, G. (2009). STÖ'ler İçin Gönüllülük ve Gönüllü Yönetimi, Özel Sektör Gönüllüleri Derneği, Fersa Matbaacılık. Ankara.

Gratton, C., Nichols, G., Shibli, S. and Taylor, P. (1997). Valuing Volunteers in UK Sport, Sports Council, England. 
Green, B. C. ve Chalip, L. (2004). Paths to volunteer commitment: Lessons from the Sydney Olympic Games. In R. A. Stebbins ve M. M. Graham (Eds.), Volunteering as leisure/leisure as volunteering: An international assessment (49-68). Wallingford, Oxon, UK: CAB International.

Güçlü, B., Türkmenoğlu, İ., Ilgaz, P. ve Akman, S. (2013). Kurumsal Gönüllülük Programları El Kitabı, Özel Sektör Gönüllüleri Derneği, Elit Ofset Matbaacılık. İstanbul.

Güder, N. (2006). STK'lar İçin Gönüllülük ve Gönüllü Yönetimi Rehberi. Ankara.

Güngör, N. (2014). The Volunteerism concept (notion) in sports organisations and reflections within Turkey. Yayımlanmamış Yüksek Lisans Tezi, Bahçeşehir Üniversitesi, Sosyal Bilimler Enstitüsü, İstanbul.

Güzel P., Ünlü H. (2015). "Volunteerism And International Sport Organisations: XVII. Mediterranean Games". Journal of Sport and Exercise, 17(1), 84-91.

Hazar, A. (2007). Spor ve turizm: BESYO Spor ve Turizm, Spor Turizmi, Turizm Kaynakları dersi için. Detay Yayınları.

Hoye, R., Smith, A., Westerbeek, H., Stewart, B. ve Nicholson, M. (2006). Sport Management. Oxford: Elsevier Ltd.

Kemp, S. (2002). "The Hidden Workforce: Volunteers' Learning in the Olympics". Journal of European Industrial Training. 26(2/3/4): 109-16.

Kumnig, M., Schnitzer, M., Beck, T. N., Mitmansgruber, H., Jowsey, S. G., Kopp M. ve Rumpold, G. (2015). Approach and Avoidance Motivations Predict Psychological Well-Being and Affectivity of Volunteers at the Innsbruck 2008 Winter Special Olympics. Voluntas. 26: 801-822.

Mallen, C. ve Adams, L. J. (2008). Sport, recreation and tourism event management: theoretical and practical dimensions. Routledge.

Mirsafian, H. ve Mohamadinejad, A. (2011). Sport volunteerism: A study on volunteering motivations in university students. Journal of Human Sport and Exercise, 7(1 Special Issue), 11-14.

Neufeind, M., Güntert, S. T. ve Wehner T. (2013). "The İmpact Of Job Design on Event Volunteers' Future Engagement: İnsights From The European Football Championship 2008". European Sport Management Quarterly. 13(5): 537-556. Osmanoğlu, H. (2017). Spor Turizmi Yapan Otel İşletmelerinin Hizmet Kalitesinin Sporcular Açısından Değerlendirilmesi. Yayımlanmamış Doktora Tezi, Abant 
İzeet Baysal Üniversitesi, Sosyal Bilimler Enstitüsü, Spor Yöneticiliği Anabilim Dalı, Spor Yöneticiliği Bilim Dalı, Bolu.

Parks, J. B., Quarterman, J. ve Thibault, L. (2013). (13. Basım). Çağdaş Spor Yönetimi. Çev. G. Doğu., D. Sevimli., A. Durusoy. Ankara: Akademisyen Kitabevi.

Pehlivan, E. (2010). Ulaşım Faaliyetlerinin Turizm Faaliyetlerine Etkisi (İstanbul Örneği). Yayımlanmamış Yüksek Lisans Tezi, İstanbul Teknik Üniversitesi, İstanbul.

Ringuet, C. (2012). Volunteers in sport: Motivations and commitment to volunteer roles. Aspetar Sports Med J, 1, 154-161.

Ross, S. (2001). Developing Sports Tourism. An eGuide for Destination Marketers and Sports Events Planners, National Laboratory for Tourism and eCommerce, 122.

Slack, T. ve Parent, M. M. (2006). Understanding sport organizations: The application of organization theory. Human Kinetics.

Sunay, H. (2010). Sporda Organizasyon. Gazi Kitabevi: Ankara.

T.C. Kültür ve Turizm Bakanlığı (2019). 2019 Yılı Turizm Verileri. Ankara.

Tarınç, A. (2019). Alternatif Turizm Çeşitliliği Kazandırmak Amacı ile Gönüllü Turizm: Türkiye Uygulaması. Yayımlanmamış Yüksek Lisans Tezi, Selçuk Üniversitesi, Sosyal Bilimler Enstitüsü, Turizm İşletmeciliği Anabilim Dalı, Turizm Iş̧letmeciliği Bilim Dalı, Konya. 